\title{
Quantum chemical calculations of stability constants: study of ligand effects on the relative stability of $\mathrm{Pd}(\mathrm{II})$-peptide complexes
}

\author{
Elkin Tílvez • Natalia Díaz • M. Isabel Menéndez • \\ Dimas Suárez $\cdot$ Ramón López
}

Received: 29 June 2010/ Accepted: 18 November 2010/Published online: 5 December 2010

(C) Springer-Verlag 2010

\begin{abstract}
Replacement of $\left[\mathrm{Pd}\left(\mathrm{H}_{2} \mathrm{O}\right)_{4}\right]^{2+}$ by cis-[Pd(en) $\left.\left(\mathrm{H}_{2} \mathrm{O}\right)_{2}\right]^{2+},\left[\mathrm{PdCl}_{4}\right]^{2-}$, and $\left[\mathrm{Pd}\left(\mathrm{NH}_{3}\right)_{4}\right]^{2+}$ on the hydrolytic cleavage of the Ace-Ala-Lys-Tyr-Gly-Gly-Met-Ala-AlaArg-Ala peptide is theoretically investigated by using different quantum chemical methods both in the gas phase an in water solution. First, we carry out a series of validation calculations on small Pd(II) complexes by computing highlevel ab initio [MP2 and CCSD(T)] and Density Functional Theory (B3LYP) electronic energies while solvent effects are taken into account by means of a Poisson-Boltzmann continuum model coupled with the B3LYP method. After having assessed the actual performance of the DFT calculations in predicting the stability constants for selected $\mathrm{Pd}(\mathrm{II})$-complexes, we compute the relative free energies in solution of several Pd(II)-peptide model complexes. By assuming that the reaction of the peptide with cis$\left[\mathrm{Pd}(\mathrm{en})\left(\mathrm{H}_{2} \mathrm{O}\right)_{2}\right]^{2+},\left[\mathrm{Pd}(\mathrm{Cl})_{4}\right]^{2-}$, and $\left[\mathrm{Pd}\left(\mathrm{NH}_{3}\right)_{4}\right]^{2+}$ would lead to the initial formation of the respective peptide-bound complexes, which in turn would evolve to afford a hydrolytically active complex $\left[\mathrm{Pd}(\text { peptide })\left(\mathrm{H}_{2} \mathrm{O}\right)_{2}\right]^{2+}$ through the displacement of the en, $\mathrm{Cl}^{-}$, and $\mathrm{NH}_{3}$ ligands by water, our calculations of the relative stability of these complexes allow us to rationalize why $\left[\mathrm{Pd}\left(\mathrm{H}_{2} \mathrm{O}\right)_{4}\right]^{2+}$ and
\end{abstract}

Published as part of the special issue celebrating theoretical and computational chemistry in Spain.

Electronic supplementary material The online version of this article (doi:10.1007/s00214-010-0862-z) contains supplementary material, which is available to authorized users.

E. Tílvez · N. Díaz · M. I. Menéndez · D. Suárez ·

R. López $(\bowtie)$

Departamento de Química Física y Analítica,

Facultad de Química, Universidad de Oviedo,

C/Julián Clavería, 8, 33006 Oviedo, Asturias, Spain

e-mail: rlopez@uniovi.es
$\left[\mathrm{Pd}\left(\mathrm{NH}_{3}\right)_{4}\right]^{2+}$ are more reactive than cis-[Pd(en $\left.)\left(\mathrm{H}_{2} \mathrm{O}\right)_{2}\right]^{2+}$ and $\left[\mathrm{PdCl}_{4}\right]^{2-}$ as experimentally found.

Keywords Palladium complexes - Ligand effects · Peptide hydrolysis · Stability constants · Quantum mechanical calculations

\section{Introduction}

Hydrolytic cleavage of the amide bond in peptides and proteins is a very important issue due to its implication in many bioanalytical and bioengineering applications such as protein sequencing, peptide mapping, protein footprinting and folding studies, protein semisynthesis, and purification of fusion proteins [1-6]. The extreme inertness of the amide linkage to be hydrolyzed has prompted the emerging of different procedures to overcome such an inconvenience [7-10]. Among them, the use of transition-metal complexes constitutes one of the most promising strategies for cleaving peptides and proteins because mild conditions can be employed [2, 3, 5, 7, 9-16]. Besides this, the relatively small size of these complexes favors the probing of the conformation or accessibility of protein regions $[3,13,17$, 18], which can also be important to get a better knowledge on natural metalloproteases.

Numerous experimental studies have shown that palladium (II) and platinum (II) complexes are useful reagents for cleaving peptides and proteins [15, 19-41]. Particularly, the complex $\left[\mathrm{Pd}\left(\mathrm{H}_{2} \mathrm{O}\right)_{4}\right]^{2+}$ has been studied in some detail because of its relatively high effectiveness [15, 25, 28]. This complex spontaneously binds to the side chains of either methionine (Met) or histidine (His) residues and regioselectively promotes the hydrolytic cleavage of the second amide bond upstream from the anchoring residue, 
Scheme 1 Binding of Pd(II) ion to the Met side chain followed by the stepwise coordination of the deprotonated $\mathrm{NH}$ groups in the peptide backbone upstream from the anchor

\section{Gly-Met-peptide}

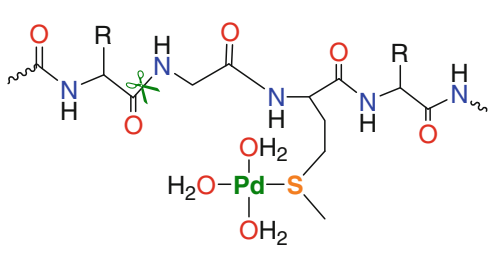

1

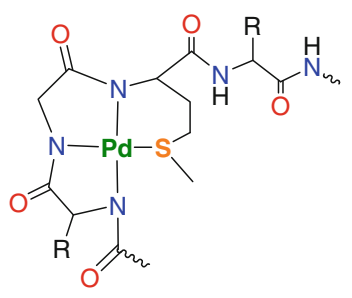

4, inactive

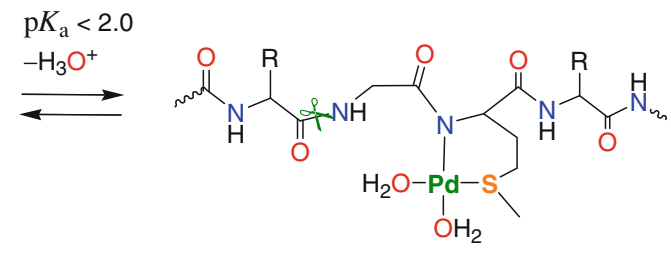

2, active
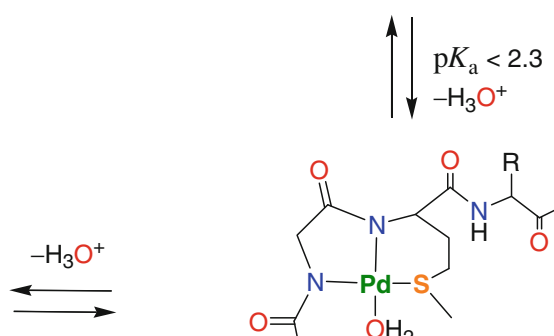

3, inactive that is, for instance, the Gly-Gly and Gly-Pro bonds in the Gly-Gly-Met (or Gly-Gly-His) and Gly-Pro-Met (or GlyPro-His) peptide sequences, respectively (see Scheme 1) $[15,25,28]$. These processes start with the complexation of the peptide, in which the metal ion anchors to the sulfur or nitrogen atoms of the Met or His residues, respectively (see 1 in Scheme 1 for the Met case). Then, the Pd (II) ion deprotonates the secondary amide group and binds to the nitrogen atom of the resulting amidate anion, thus giving the so-called hydrolytically active complex (see 2 in Scheme 1). This mechanistic proposal has gained much support in our recent computational work [42] confirming that only $\left[\mathrm{Pd} \text { (peptide) }\left(\mathrm{H}_{2} \mathrm{O}\right)_{2}\right]^{+}$complexes, in which the scissile peptide bond has a trans conformation, possess the adequate structure and stability for being hydrolytically active. Our calculations, which are in consonance with the most important experimental facts and their interpretation, have also uncovered the critical roles played by both the $\mathrm{Pd}$-peptide dicoordination environment and one of the Pdbound water molecules during the hydrolysis reaction. In this scenario, other plausible Pd-peptide complexes lacking these two essential features, Pd-peptide dicoordination and Pd-bound water, would not be reactive.

An experimental investigation into the $\left[\mathrm{Pd}\left(\mathrm{H}_{2} \mathrm{O}\right)_{4}\right]^{2+}$ catalyzed hydrolysis of the peptide Ace-Ala-Lys-Tyr-GlyGly-Met-Ala-Ala-Arg-Ala at $\mathrm{pH} 1.8$ has revealed that the replacement of $\left[\mathrm{Pd}\left(\mathrm{H}_{2} \mathrm{O}\right)_{4}\right]^{2+}$ by cis-[Pd(en) $\left.\left(\mathrm{H}_{2} \mathrm{O}\right)_{2}\right]^{2+}$, $\left[\mathrm{PdCl}_{4}\right]^{2-}$, and $\left[\mathrm{Pd}\left(\mathrm{NH}_{3}\right)_{4}\right]^{2+}$ does not change the regioselectivity, but affects the rate of the reaction [28]. According to the rate constants experimentally obtained, $\left[\mathrm{Pd}\left(\mathrm{H}_{2} \mathrm{O}\right)_{4}\right]^{2+}$ and $\left[\mathrm{Pd}\left(\mathrm{NH}_{3}\right)_{4}\right]^{2+}$ are better cleavage promoters than cis-[Pd(en) $\left.\left(\mathrm{H}_{2} \mathrm{O}\right)_{2}\right]^{2+}$ and $\left[\mathrm{PdCl}_{4}\right]^{2-}$. However, the reason why this happens remains unclear. Thus, for instance, the initial delay experimentally observed in the peptide hydrolysis by cis- $\left[\mathrm{Pd}(\mathrm{en})\left(\mathrm{H}_{2} \mathrm{O}\right)_{2}\right]^{2+}$ compared to $\left[\mathrm{Pd}\left(\mathrm{H}_{2} \mathrm{O}\right)_{4}\right]^{2+}$ has been ascribed to a relatively slow displacement of the en ligand by the sulfur and nitrogen donor atoms of the peptide Met residue [28]. However, it has also been proposed that the more labile Pdbound water molecules are initially displaced by the peptide molecule from the cis- $\left[\mathrm{Pd}(\mathrm{en})\left(\mathrm{H}_{2} \mathrm{O}\right)_{2}\right]^{2+}$ complex to form $c i s-[\operatorname{Pd}(p e p)(e n)]^{+}$. Then, after a relatively slow replacement of the en ligand by water in a process assisted by the acidic solvent, the Pd(II) ion would cleave the scissile peptide bond [28].

In this work, we aim at rationalizing the experimentally observed ligand effects on the hydrolytic cleavage of the Gly-Gly-Met peptide sequence. Based on the details of the theoretical hydrolysis mechanism as well as on the experimental kinetic data, the lower reaction rate in the presence of cis-[Pd(en) $\left.\left(\mathrm{H}_{2} \mathrm{O}\right)_{2}\right]^{2+}$ and $\left[\mathrm{PdCl}_{4}\right]^{2-}$ could be a consequence of a larger stability of the $[\operatorname{Pd}(\text { peptide })(e n)]^{+}$and $\left[\mathrm{Pd} \text { (peptide) } \mathrm{Cl}_{2}\right]^{-}$complexes with respect to the hydrolytically active $\left[\mathrm{Pd}(\text { peptide })\left(\mathrm{H}_{2} \mathrm{O}\right)_{2}\right]^{+}$. To further clarify the origin of the ligand kinetic effects, theoretical calculations of stability constants could be very useful. In this respect, and taking into account the relatively large size of the Pdpeptide complex models, it is clear that Density Functional Theory (DFT) methods offer a priori the best compromise between accuracy and computational cost for performing the required calculations. Nevertheless, we carry out a series of validation calculations on small $\mathrm{Pd}(\mathrm{II})$ complexes 
using high-level ab initio calculations. Then, we apply a composite quantum mechanical protocol for determining the relative stability of a series of [Pd (peptide)(L)] complexes $\left(\mathrm{L}=\mathrm{H}_{2} \mathrm{O}\right.$, en, $\mathrm{Cl}^{-}$, and $\mathrm{NH}_{3}$ ). The influence of the $\mathrm{pH}$ on the stability of the reactive $[\mathrm{Pd}$ (peptide $\left.)\left(\mathrm{H}_{2} \mathrm{O}\right)_{2}\right]^{+}$ complex is also assessed. Overall, our results fulfill a twofold goal: (a) they give new insight into the ligand effects on the hydrolysis of the $\mathrm{Pd}(\mathrm{II})$-peptide complexes, and (b) they support the use of quantum chemical calculations to estimate the relative stability constants of $\mathrm{Pd}(\mathrm{II})$ complexes, what could be of interest for the computational design of other metal complexes for the regioselective cleavage of peptides and proteins.

\section{Computational details}

\subsection{Gas-phase calculations on test systems}

From previous computational experience in metal-containing systems, the error on the relative energies computed by DFT methodologies is unlikely to exceed a range of $3-5 \mathrm{kcal} / \mathrm{mol}$ [43]. Nevertheless, exceptions exist and, therefore, the performance of the B3LYP [44-46] method when compared with ab initio methodologies is reassessed in this work. Thus, we performed a series of validation calculations on small palladium(II) compounds that are relevant to the coordination environment of the $\mathrm{Pd}(\mathrm{II})$ ion in the metal-peptide complexes. The gas-phase acidity of acetamide, ammonia and ethylamine is also considered in the test calculations given that binding of $\mathrm{Pd}(\mathrm{II})$ to the peptide backbone implies the deprotonation of $\mathrm{NH}$ groups, while the $\mathrm{NH}_{3}$ and en ligands would be protonated at the acidic pHs required for the regioselective $\mathrm{Pd}(\mathrm{II})$-assisted peptide hydrolysis.

Molecular geometries were optimized using the DFT B3LYP method and the ab initio MP2 method. In both cases, we employed a correlation consistent basis set of triple- $\zeta$ quality: aug-cc-pVTZ for the non-metal atoms plus the cc-pVTZ-PP basis set with extended relativistic pseudo-potentials for Pd [47-51]. Given the acceptable similarity between the B3LYP and MP2 optimized geometries (see below), the nature of the critical points found was only checked by harmonic frequency calculations at the B3LYP/aug-cc-pVTZ (cc-pVTZ-PP for Pd) level.

Electronic energies were refined by performing singlepoint calculations at the $\operatorname{CCSD}(\mathrm{T}) /$ aug-cc-pVTZ (ccpVTZ-PP for Pd) level of theory (coupled cluster single and double excitation augmented with a noniterative treatment of triple excitations) [52] on the MP2/aug-ccpVTZ (cc-pVTZ-PP for Pd) geometries. The effect of larger basis sets on the ab initio energies was also estimated by doing MP2/aug-cc-pVnZ//MP2/aug-cc-pVTZ $(n=\mathrm{Q}, 5)$ calculations [47-51]. To extrapolate our results toward the complete basis set (CBS) limit and, thereby, remove basis set truncation errors, we used the Schwarz's extrapolation formula for correlation energy:

$E_{n}=E_{\mathrm{CBS}}+A n^{-3}$

where $n$ is the cardinal number of the basis set and $E_{\mathrm{CBS}}$ and $A$ are fitting parameters, with $E_{\mathrm{CBS}}$ being the resulting estimate of the CBS limit of correlation energy. Herein, CBS extrapolations with the aug-cc-pVnZ $(n=\mathrm{Q}, 5)$ basis sets were used systematically on the MP2 correlation energies. The HF energies were not extrapolated, and the $5 \mathrm{Z}$ values were simply taken as the most accurate estimates of the HF limit. Then, the following "composite" formula was used to obtain a better estimate of the electronic energy:

$$
\begin{aligned}
E_{\mathrm{CCSD}(\mathrm{T}) / \mathrm{CBS}} \approx & E_{\mathrm{MP} 2 / \mathrm{CBS}} \\
& +\left(E_{\mathrm{CCSD}(\mathrm{T}) / \text { aug }-\mathrm{cc}-\mathrm{pVTZ}}-E_{\mathrm{MP} 2 / \text { aug }-\mathrm{cc}-\mathrm{pVTZ}}\right)
\end{aligned}
$$

The frozen core approximation was used in all the correlated ab initio calculations. B3LYP and MP2 calculations were done using the Gaussian 03 [53] and TURBOMOLE [54] packages, respectively, while the MOLPRO code [55] was used for the $\operatorname{CCSD}(\mathrm{T})$ computations [56]. The MP2 calculations were performed in the framework of the "resolution-of-the-identity" approximation (RI-MP2) using the appropriate auxiliary basis set.

\subsection{Solvent effects and calculation of equilibrium constants}

To take into account condensed-phase effects, we used a Self-Consistent-Reaction-Field (SCRF) model proposed for quantum mechanical computations on solvated molecules $[57,58]$. The solvent is represented by a dielectric continuum characterized by its relative static dielectric permittivity $\varepsilon$. The solute, which is placed in a cavity created in the continuum after spending some cavitation energy, polarizes the continuum, which in turn creates an electric field inside the cavity. This interaction can be taken into account using quantum chemical methods by minimizing the electronic energy of the solute plus the Gibbs energy change corresponding to the solvation process [59]. Among the different approaches that can be followed to calculate the electrostatic potential created by the polarized continuum in the cavity, we employed the Poisson-Boltzmann (PB) model as implemented in the JAGUAR program [60]. $\Delta G_{\text {solv }}$ values were evaluated through geometry reoptimizations of all the species in solution at the PBB3LYP/LACVP* $+[61,62]$ level, excepting $\mathrm{H}^{+}$and $\mathrm{H}_{2} \mathrm{O}$ (see below). A relative permittivity of 80.37 was employed to simulate water as the solvent used in the experimental 
work. In these calculations, we used the LACVP*+ basis, which comprises the $6-31+G^{*}$ basis set for non-metal atoms and the Los Alamos effective core potentials for palladium, as larger basis sets including diffuse and polarization functions hardly change the aqueous solvation effects [63].

For all the species, Gibbs energies in solution $\left(G_{\text {solution }}\right)$ were computed by adding the Gibbs energies of solvation $\left(\Delta G_{\text {solv }}\right)$ to Gibbs energies in the gas phase $\left(G_{\text {gas }}\right)$. The $G_{\text {gas }}$ values were obtained by combining the B3LYP/augcc-pVTZ electronic energies with the gas-phase thermal corrections evaluated at the B3LYP/aug-cc-pVTZ(ccpVTZ-PP for Pd) level (for the test calculations on small systems) or the B3LYP/aug-cc-pVDZ(cc-pVDZ-PP for Pd) [47-51] level (for the QM cluster models of the Pd-peptide complexes, see below). Thermodynamic magnitudes were computed within the ideal gas, rigid rotor, and harmonic oscillator approximations at a pressure of $1 \mathrm{~atm}$ and a temperature of $298.15 \mathrm{~K}$. To obtain $G_{\text {solution }}$ values at the standard state of $1 \mathrm{M}$, it must be taken into account that the translational entropy for each species is smaller by $6.4 \mathrm{cal} \mathrm{mol}^{-1} \mathrm{~K}^{-1}$ than the entropy value obtained for the standard state of an (ideal) gas ( $1 \mathrm{~atm}, 298.15 \mathrm{~K} \rightarrow$ $0.041 \mathrm{M})$. For water, a standard concentration of $55 \mathrm{M}$ was taken.

The standard free energy of a proton that is needed to compute $\mathrm{p} K_{\mathrm{a}}$ values was estimated by combining the gasphase free energy of a proton $\left(\frac{5}{2} R T-T S_{\text {gas }}=1.48-7.76=\right.$ $-6.28) \mathrm{kcal} / \mathrm{mol}$ at $298 \mathrm{~K}$ and $1 \mathrm{~atm})$ with its solvation free energy $\left(\Delta G_{\text {solv }}\left(\mathrm{H}^{+}\right)\right)$. Here, $\Delta G_{\text {solv }}\left(H^{+}\right)$was treated as a parameter chosen to give the best match between calculated and experimental $\mathrm{p} K_{\mathrm{a}}$ values for methylamine. The selected $\Delta G_{\text {solv }}\left(H^{+}\right)=-266.0 \mathrm{kcal} / \mathrm{mol}$ is in good agreement with the typical literature values [64]. On the other hand, we used the experimental solvation free energy for water $\left(\Delta G_{\text {solv }}\left(\mathrm{H}_{2} \mathrm{O}\right)=-6.3 \mathrm{kcal} / \mathrm{mol}\right)[65]$ in the calculations of stability constants for Pd-complexes as we found that this value, which is $3.2 \mathrm{kcal} / \mathrm{mol}$ less negative than the PBB3LYP/LACVP*+ one, improves the agreement between theoretical and experimental data for the small complexes.

\subsection{QM calculations on the Pd-peptide cluster models}

In our previous work [42], we found that (a) the central region of the peptide molecules nearby the $\mathrm{Pd}(\mathrm{II})$ ion is conformationally rigid, and (b) QM calculations on truncated models of the peptide molecules (Ace-Gly-Gly-MetNme or Ace-Gly-Gly-Pro-Nme) can reproduce both the structure of the first coordination shell around the Pd(II) ion and the relative stability of various coordination modes. Assuming that exchange of water by other ligands at the Pd(II) site would mainly affect the Pd-ligand bond energies, the stability of the Pd-peptide complexes is then evaluated using again a truncated peptide model (Ace-GlyGly-Met-Nme).

Initial geometries for the QM cluster models were built based on the structure of the complexes studied in our previous work [42]. The augmented correlation basis sets aug-cc-pVnZ (cc-pVTZ-PP for Pd) with $n=\mathrm{D}$, T, in conjunction with the hybrid density functional method B3LYP, were used to fully optimize all the critical structures. The structures were first optimized and their nature as energy minima on the Potential Energy Surface confirmed by analytical computations of harmonic vibrational frequencies at the B3LYP/aug-cc-pVDZ (cc-pVDZ-PP for Pd) level. Subsequently, the structures were reoptimized at the B3LYP/aug-cc-pVTZ (cc-pVTZ-PP for Pd) level. As the molecular geometries obtained with the double- and triple- $\zeta$ correlation consistent basis sets were quite similar, we did not carry out the computationally very costly frequency calculations using the larger basis set (aug-ccpVTZ). For the sake of brevity, we only report the molecular geometries at the B3LYP/aug-cc-pVTZ (ccpVTZ-PP for Pd) level.

All the quantum chemical computations at the B3LYP/ aug-cc-pVDZ (cc-pVDZ-PP for Pd) theory level and only those at the B3LYP/aug-cc-pVTZ (cc-pVTZ-PP for Pd) theory level involving molecular systems other than Pep and Pd(II)-Pep complexes were carried out with the Gaussian 03 series of program [53]. To perform the B3LYP/aug-cc-pVTZ (cc-pVTZ-PP for Pd) calculations on the Pd-peptide complexes, we employed the TURBOMOLE V5.9 code [54] selecting the B3LYP version equivalent to that implemented in Gaussian 03. Gibbs free energies in the gas phase and in solution were computed using the prescriptions above described (i.e., all the structures were reoptimized in solution at the PB-B3LYP/ LACVP*+ level).

\section{Results and discussion}

\subsection{Validation computations}

Before presenting and discussing the obtained results for the Pd-peptide models, we corroborate the adequacy of the B3LYP/aug-cc-pVTZ(cc-pVTZ-PP for Pd) level for computing their molecular geometry and electronic energy by performing ab initio benchmarking calculations based on MP2/aug-cc-pVTZ(cc-pVTZ-PP for Pd) geometry optimizations followed by single-point calculations at the CCSD(T)/aug-cc-pVTZ(cc-pVTZ-PP for Pd) and MP2/ aug-cc-pVnZ(cc-pVXZ-PP for Pd) with $n=\mathrm{Q}, 5$ levels of theory. To accomplish this task, we selected a series of proton dissociation and ligand exchange processes on small molecules with the aim of ranging over most of the 
Table 1 Electronic reaction energies (in $\mathrm{kcal} / \mathrm{mol}$ ) obtained with different quantum chemical computational protocols

\begin{tabular}{|c|c|c|c|c|c|c|c|}
\hline Reaction & $\begin{array}{l}\text { B3LYP/ } \\
\text { aug-cc- } \\
\text { pVTZ }\end{array}$ & $\begin{array}{l}\text { MP2/aug- } \\
\text { cc-pVTZ }\end{array}$ & $\begin{array}{l}\text { MP2/aug- } \\
\text { cc-pVQZ }\end{array}$ & $\begin{array}{l}\text { MP2/aug- } \\
\text { cc-pV5Z }\end{array}$ & $\begin{array}{l}\mathrm{MP} 2 / \\
\mathrm{CBS}^{\mathrm{b}, \mathrm{c}}\end{array}$ & $\begin{array}{l}\operatorname{CCSD}(\mathrm{T}) / \\
\text { aug-cc- } \\
\text { pVTZ }^{\mathrm{b}}\end{array}$ & $\begin{array}{l}\text { Composite } \\
\text { energy }^{\text {d }}\end{array}$ \\
\hline \multicolumn{8}{|l|}{ Proton dissociation } \\
\hline $\mathrm{CH}_{3} \mathrm{CONH}_{2} \rightarrow \mathrm{CH}_{3} \mathrm{CONH}^{-}+\mathrm{H}^{+}$ & 369.9 & 366.8 & 367.0 & 367.0 & 366.9 & 369.1 & 368.9 \\
\hline $\mathrm{CH}_{3} \mathrm{CH}_{2} \mathrm{NH}_{3}^{+} \rightarrow \mathrm{CH}_{3} \mathrm{CH}_{2} \mathrm{NH}_{2}+\mathrm{H}^{+}$ & 226.2 & 225.0 & 224.9 & 224.8 & 224.7 & 226.5 & 226.2 \\
\hline $\mathrm{NH}_{4}^{+} \rightarrow \mathrm{NH}_{3}+\mathrm{H}^{+}$ & 211.1 & 210.6 & 210.6 & 210.5 & 210.4 & 211.8 & 211.6 \\
\hline$\left[\mathrm{Pd}\left(\mathrm{H}_{2} \mathrm{O}\right)_{4}\right]^{2+} \rightarrow\left[\mathrm{Pd}\left(\mathrm{H}_{2} \mathrm{O}\right)_{3}(\mathrm{OH})\right]^{+}+\mathrm{H}^{+}$ & 126.0 & 122.5 & 122.0 & 121.7 & 121.1 & 125.5 & 124.5 \\
\hline \multicolumn{8}{|l|}{ Ligand exchange } \\
\hline$\left[\mathrm{Pd}\left(\mathrm{H}_{2} \mathrm{O}\right)_{4}\right]^{2+}+\mathrm{NH}_{3} \rightarrow\left[\mathrm{Pd}\left(\mathrm{H}_{2} \mathrm{O}\right)_{3}\left(\mathrm{NH}_{3}\right)\right]^{2+}+\mathrm{H}_{2} \mathrm{O}$ & -24.8 & -28.9 & -29.0 & -28.9 & -28.8 & -26.5 & -26.3 \\
\hline$\left[\mathrm{Pd}\left(\mathrm{H}_{2} \mathrm{O}\right)_{4}\right]^{2+}+\mathrm{Cl}^{-} \rightarrow\left[\mathrm{Pd}\left(\mathrm{H}_{2} \mathrm{O}\right)_{3}(\mathrm{Cl})\right]^{+}+\mathrm{H}_{2} \mathrm{O}$ & -227.7 & -231.7 & -233.5 & -234.4 & -235.2 & -229.8 & -233.3 \\
\hline $\begin{array}{l}{\left[\mathrm{Pd}\left(\mathrm{H}_{2} \mathrm{O}\right)_{4}\right]^{2+}+2 \mathrm{Cl}^{-} \rightarrow \text { trans- }} \\
{\left[\mathrm{Pd}\left(\mathrm{H}_{2} \mathrm{O}\right)_{2}(\mathrm{Cl})_{2}\right]+\mathrm{H}_{2} \mathrm{O}}\end{array}$ & -357.3 & -364.6 & -367.6 & -369.2 & -370.6 & -360.4 & -366.4 \\
\hline$\left[\mathrm{Pd}\left(\mathrm{H}_{2} \mathrm{O}\right)_{4}\right]^{2+}+4 \mathrm{Cl}^{-} \rightarrow\left[\mathrm{Pd}(\mathrm{Cl})_{4}\right]^{2-}+4 \mathrm{H}_{2} \mathrm{O}$ & -340.4 & -350.6 & -356.2 & -358.9 & -361.5 & -342.6 & -353.6 \\
\hline
\end{tabular}

\footnotetext{
${ }^{a}$ Using the cc-pVTZ-PP basis set for Pd

b Single-point calculations on the MP2/aug-cc-pVTZ geometries

c Obtained from CBS extrapolation of the VQZ and V5Z energies and using the HF/aug-cc-pV5Z energies

${ }^{\mathrm{d}} E_{\mathrm{MP} 2 / \mathrm{CBS}}+\left(E_{\mathrm{CCSD}(\mathrm{T}) / \text { aug-cc-pVTZ }}-E_{\mathrm{MP} 2 / \text { aug-cc-pVTZ }}\right)$
}

chemical features involved in the larger Pd-peptide complexes.

In general, the MP2 and B3LYP molecular geometries of the test compounds are very similar to each other. Thus, the MP2 computed bond lengths and bond angles of the structures involved in the gas-phase acidity of acetamide, ammonia, and ethylamine differ from the B3LYP values by only $(-1.0 \%)$ to $(+0.4 \%)$ and $(-1.0 \%)$ to $(+0.2 \%)$, respectively. More significant deviations were found when comparing the B3LYP and MP2 geometries of the complexes $\left[\mathrm{Pd}\left(\mathrm{H}_{2} \mathrm{O}\right)_{4}\right]^{2+}, \quad\left[\mathrm{Pd}\left(\mathrm{NH}_{3}\right)\left(\mathrm{H}_{2} \mathrm{O}\right)_{3}\right]^{2+}, \quad\left[\mathrm{Pd}\left(\mathrm{H}_{2} \mathrm{O}\right)_{3}\right.$ $(\mathrm{OH})]^{+},\left[\mathrm{Pd}\left(\mathrm{H}_{2} \mathrm{O}\right)_{3} \mathrm{Cl}\right]^{+},\left[\mathrm{PdCl}_{4}\right]^{2-}$, and trans- $\left[\mathrm{Pd}\left(\mathrm{H}_{2} \mathrm{O}\right)_{2}\right.$ $\mathrm{Cl}_{2}$ ]. All the above-mentioned $\mathrm{Pd}(\mathrm{II})$-complexes present a shortening of the metal-ligand distances ranging from $(-1.9 \%)$ to $(-4.3 \%)$ ongoing from B3LYP to MP2. The maximum relative deviations were found for $\mathrm{Cl}$-containing complexes following the sequence: $\left[\mathrm{Pd}\left(\mathrm{H}_{2} \mathrm{O}\right)_{3} \mathrm{Cl}\right]^{+}<$ trans- $\left[\mathrm{Pd}\left(\mathrm{H}_{2} \mathrm{O}\right)_{2} \mathrm{Cl}_{2}\right]<\left[\mathrm{PdCl}_{4}\right]^{2-}$. The discrepancies between the MP2 and B3LYP bond angles were only significant for the complexes $\left[\mathrm{Pd}\left(\mathrm{NH}_{3}\right)\left(\mathrm{H}_{2} \mathrm{O}\right)_{3}\right]^{2+}$ and trans $-\left[\mathrm{Pd}\left(\mathrm{H}_{2} \mathrm{O}\right)_{2} \mathrm{Cl}_{2}\right]$, which are in the range $(-5.7 \%)$ to $(+5.7 \%)$. In addition to this, it maybe also interesting to note that both the B3LYP $(2.041 \AA)$ and MP2 (1.983 $\AA$ ) $\mathrm{Pd}-\mathrm{OH}_{2}$ bond distances at $\left[\mathrm{Pd}\left(\mathrm{H}_{2} \mathrm{O}\right)_{4}\right]^{2+}$ compare well with the maximum of the $\mathrm{Pd}-\mathrm{O}$ radial distribution function at $2.04 \AA$ obtained from recent molecular dynamics (MD) simulations for aqueous solutions of $\mathrm{Pd}(\mathrm{II})$ [66]. This and other MD studies have also reported that the first solvation shell of the Pd(II)-aqua complex presents four water molecules in a square-planar conformation confirming the reasonable adequacy of considering four water ligands in our computations [66-68].
Table 1 shows the electronic reaction energy at different levels of theory for proton release from the following acids: $\mathrm{CH}_{3} \mathrm{CONH}_{2}, \mathrm{NH}_{4}{ }^{+}, \mathrm{CH}_{3} \mathrm{CH}_{2} \mathrm{NH}_{3}{ }^{+}$and $\left[\mathrm{Pd}\left(\mathrm{H}_{2} \mathrm{O}\right)_{4}\right]^{2+}$. For the extremely weak acid (acetamide) and the stronger acids, ammonium and methylammonium, the B3LYP/aug-cc-pVTZ energies closely match the best ab initio estimate provided by the composite $\operatorname{CCSD}(\mathrm{T}) /$ aug-cc-pVTZ and MP2/CBS energies, the energy differences being lower than $0.5 \mathrm{kcal} / \mathrm{mol}$. The gas-phase acidity of the $\left[\mathrm{Pd}\left(\mathrm{H}_{2} \mathrm{O}\right)_{4}\right]^{2+}$ cation is slightly less accentuated at the B3LYP/aug-cc-pVTZ, but the difference between the B3LYP and ab initio energies is also quite low, $1.5 \mathrm{kcal} /$ mol. We also computed the electronic reaction energy of ligand replacement at $\left[\mathrm{Pd}\left(\mathrm{H}_{2} \mathrm{O}\right)_{4}\right]^{2+}$ leading to the monoamin-, monochloro-, dichloro- and tetrachloro-Pd(II) complexes. In this case, we find that the discrepancy between the B3LYP and the composite ab initio reaction energies varies between 1.5 and $13.2 \mathrm{kcal} / \mathrm{mol}$, the highest deviations corresponding to the processes involving chloride ions. These results clearly indicate that the energetics of the metal-ligand bonds is more sensitive to the correlation method and basis set effects than the deprotonation energies, particularly in the case of the $\mathrm{H}_{2} \mathrm{O} \rightarrow \mathrm{Cl}^{-}$ exchange processes. Overall, we conclude that the B3LYP reaction energies for deprotonation and formation of $\left[\mathrm{Pd}\left(\mathrm{NH}_{3}\right)\left(\mathrm{H}_{2} \mathrm{O}\right)_{3}\right]^{2+}$ do not deviate significantly from the $\mathrm{CCSD}(\mathrm{T})$ and composite ones, while the relative stability of the Pd-chloride bonds tends to be underestimated by a few $\mathrm{kcal} / \mathrm{mol}$.

In addition to reliable free energies in the gas phase, the calculation of $\mathrm{p} K_{\mathrm{a}}$ 's and stability constants of metal complexes also demands accurate solvation energies for 
Table 2 B3LYP/aug-cc-pVTZ (cc-pVTZ-PP for Pd) electronic energies $(\Delta E)$ and thermal Gibbs energy corrections $\left(\Delta G_{\text {therm }}^{\text {corr }}\right)$, PB-B3LYP/ LACVP* + Gibbs energies of solvation $\left(\Delta \Delta \mathrm{G}_{\mathrm{solv}}\right)$, and Gibbs energy in solution $\left(\Delta G_{\text {solution }}\right)$ referred to the corresponding reactants

\begin{tabular}{|c|c|c|c|c|c|c|}
\hline Reaction & $\Delta E$ & $\Delta G_{\text {therm }}^{\text {corr a, b }}$ & $\Delta \Delta G_{\mathrm{solv}}^{\mathrm{c}}$ & $\Delta G_{\text {solution }}^{\mathrm{d}}$ & $\mathrm{p} K_{\mathrm{a}}($ calc $)$ & $\mathrm{p} K_{\mathrm{a}}(\exp )$ \\
\hline \multicolumn{7}{|l|}{ Proton dissociation } \\
\hline $\mathrm{CH}_{3} \mathrm{CONH}_{2} \rightarrow \mathrm{CH}_{3} \mathrm{CONH}^{-}+\mathrm{H}^{+}$ & 369.8 & -11.4 & -333.6 & 24.7 & 18.1 & $17.0[69]$ \\
\hline $\mathrm{CH}_{3} \mathrm{CH}_{2} \mathrm{NH}_{3}^{+} \rightarrow \mathrm{CH}_{3} \mathrm{CH}_{2} \mathrm{NH}_{2}+\mathrm{H}^{+}$ & 226.2 & -13.7 & -198.1 & 14.5 & 10.6 & $10.7[70]$ \\
\hline $\mathrm{NH}_{4}^{+} \rightarrow \mathrm{NH}_{3}+\mathrm{H}^{+}$ & 211.2 & -14.8 & -183.5 & 12.9 & 9.4 & $9.3[70]$ \\
\hline \multirow[t]{2}{*}[\mathrm{Pd}(\mathrm{H}_{2}\mathrm{O})_{4}]{$^{2+} \rightarrow\left[\mathrm{Pd}\left(\mathrm{H}_{2} \mathrm{O}\right)_{3}(\mathrm{OH})\right]^{+}+\mathrm{H}^{+}$} & 126.0 & -12.2 & -109.0 & 4.9 & 3.6 & $3.0[71]$ \\
\hline & & & & & $\log \beta_{n}$ (calc) & $\log \beta_{n}(\exp )$ \\
\hline \multicolumn{7}{|l|}{ Ligand exchange } \\
\hline$\left[\mathrm{Pd}\left(\mathrm{H}_{2} \mathrm{O}\right)_{4}\right]^{2+}+\mathrm{NH}_{3} \rightarrow\left[\mathrm{Pd}\left(\mathrm{H}_{2} \mathrm{O}\right)_{3}\left(\mathrm{NH}_{3}\right)\right]^{2+}+\mathrm{H}_{2} \mathrm{O}$ & -24.8 & 1.3 & 9.6 & -14.0 & 10.2 & $9.7[72]$ \\
\hline$\left[\mathrm{Pd}\left(\mathrm{H}_{2} \mathrm{O}\right)_{4}\right]^{2+}+\mathrm{Cl}^{-} \rightarrow\left[\mathrm{Pd}\left(\mathrm{H}_{2} \mathrm{O}\right)_{3}(\mathrm{Cl})\right]^{+}+\mathrm{H}_{2} \mathrm{O}$ & -227.7 & -2.0 & 224.3 & -5.4 & 3.9 & $6.1[73]$ \\
\hline$\left[\mathrm{Pd}\left(\mathrm{H}_{2} \mathrm{O}\right)_{4}\right]^{2+}+2 \mathrm{Cl}^{-} \rightarrow$ trans $-\left[\mathrm{Pd}\left(\mathrm{H}_{2} \mathrm{O}\right)_{2}(\mathrm{Cl})_{2}\right]+\mathrm{H}_{2} \mathrm{O}$ & -357.3 & -3.1 & 348.0 & -12.4 & 9.1 & $10.7[73]$ \\
\hline$\left[\mathrm{Pd}\left(\mathrm{H}_{2} \mathrm{O}\right)_{4}\right]^{2+}+4 \mathrm{Cl}^{-} \rightarrow\left[\mathrm{Pd}(\mathrm{Cl})_{4}\right]^{2-}+4 \mathrm{H}_{2} \mathrm{O}$ & -340.4 & -6.0 & 328.3 & -18.1 & 13.3 & $15.7[73]$ \\
\hline
\end{tabular}

All values are in $\mathrm{kcal} / \mathrm{mol}$. The computed and experimental $\mathrm{pK}$ values at $25{ }^{\circ} \mathrm{C}$ are also indicated

a The correction due to the standard state concentration ( $1 \mathrm{M}$ for all the species except $55 \mathrm{M}$ for $\mathrm{H}_{2} \mathrm{O}$ ) is included

${ }^{\mathrm{b}}$ Using $G_{\text {therm }}\left(\mathrm{H}^{+}\right)=5 / 2 R T-T S_{\text {gas }}=-6.28 \mathrm{cal} /(\mathrm{K} \mathrm{mol})$

${ }^{\mathrm{c}}$ Using $\Delta G_{\text {solv }}\left(\mathrm{H}_{2} \mathrm{O}\right)=-6.3 \mathrm{kcal} / \mathrm{mol}(\exp ) ; \Delta G_{\text {solv }}\left(\mathrm{H}^{+}\right)=-266.0 \mathrm{kcal} / \mathrm{mol}$

${ }^{\mathrm{d}} \Delta G_{\text {solution }}=\Delta E+\Delta G_{\text {therm }}^{\text {corr }}+\Delta \Delta G_{\text {solv }}$

the different species involved. Hence, after having calibrated the electronic B3LYP/aug-cc-pVTZ energies, it is equally important to assess the performance of the Gibbs solvation energies for computing equilibrium constants. To this end, we evaluated the free energies and the equilibrium constant in aqueous solution for the deprotonation and ligand exchange reactions above considered, and for which experimental data are available (see Table 2). As mentioned in the Computational Details, we employed the PB-B3LYP/LACVP*+ level of theory to compute the solvation energies, excepting those of $\mathrm{H}^{+}$ and bulk $\mathrm{H}_{2} \mathrm{O}$, which were chosen to give the best agreement with experimental data. Thus, by adjusting $\Delta G_{\text {solvation }}\left(H^{+}\right)$to $-266.0 \mathrm{kcal} / \mathrm{mol}$, the computed $\mathrm{p} K_{\mathrm{a}}$ 's for $\mathrm{CH}_{3} \mathrm{CONH}_{2}, \mathrm{NH}_{4}^{+}, \mathrm{CH}_{3} \mathrm{NH}_{3}{ }^{+}$and $\left[\mathrm{Pd}\left(\mathrm{H}_{2} \mathrm{O}\right)_{4}\right]^{2+}$ are all within $\sim 1 \mathrm{pK}$ unit from the experimental ones (see Table 2). Therefore, we believe that this degree of agreement is quite remarkable considering the diverse nature and acid strength of these molecules (note also that in these calculations the gas-phase Gibbs energy is obtained at the B3LYP/aug-cc-pVTZ level). We note in passing that the geometry relaxation effects accounted for by the PB-B3LYP/LACVP*+ solvation energies are relatively important for obtaining reliable $\mathrm{p} K_{\mathrm{a}}$ predictions for the species studied in this work. For example, the computed $\mathrm{p} K_{\mathrm{a}}$ values for $\left[\mathrm{Pd}\left(\mathrm{H}_{2} \mathrm{O}\right)_{4}\right]^{2+}$ are 0.90 (single-point calculations on the gas-phase geometries) and 3.59 (solvation energies derived from the fully relaxed structures in solution), the experimental $\mathrm{p} K_{\mathrm{a}}$ value being 3.0 (this effect can be traced back to a slightly loss of planarity upon solvation of the coordination polyhedra in the $\left[\mathrm{Pd}\left(\mathrm{H}_{2} \mathrm{O}\right)_{3}(\mathrm{OH})\right]^{+}$complex $)$.

For the $\left[\mathrm{Pd}(\mathrm{L})_{\mathrm{i}}\left(\mathrm{H}_{2} \mathrm{O}\right)_{4-\mathrm{i}}\right]$ complexes with $\mathrm{L}=\mathrm{NH}_{3}$, $\mathrm{Cl}^{-}$, their stability constants are expressed in the form of cumulative constants $\left(\log \beta_{n}\right.$ ) (see Table 2 ). The combination of the B3LYP/aug-cc-pVTZ electronic energies with the PB-B3LYP/LACVP*+ solvation energies gives a quite reasonable value for the $\log \beta_{1}\left(\mathrm{NH}_{3}\right)$ constant, 10.2, which is only $0.5 \log$ units above the experimental value. For the Pd-chloro complexes, the resulting $\log \beta$ constants are about 2 units below the experimental ones, what is not entirely unexpected given that the B3LYP/aug-cc-ppVTZ reaction energies deviate from the ab initio values by $2-13 \mathrm{kcal} / \mathrm{mol}$ although it also seems that the $\log \beta$ calculations for $\mathrm{Cl}^{-}$ligands benefit from a partial cancelation of errors. With all these results in mind, we note that our computational protocol based on the B3LYP method would be more adequate to determine the relative stability of the complexes $[\mathrm{Pd}(\mathrm{L})$ (peptide) $]\left(\mathrm{L}=\mathrm{H}_{2} \mathrm{O}\right.$, en, $\left.\mathrm{NH}_{3}\right)$ than those including $\mathrm{L}=\mathrm{Cl}^{-}$.

\subsection{Pd-peptide cluster models}

As mentioned in the Introduction, our previous calculations have revealed that $\left[\mathrm{Pd}\left(\mathrm{H}_{2} \mathrm{O}\right)_{4}\right]^{2+}$ can promote hydrolysis of the Ace-Ala-Lys-Tyr-Gly-Gly-Met-Ala-Ala-Arg-Ala peptide through an external attack of a water molecule to the scissile Gly-Gly peptide bond in trans conformation (see Scheme 2) [42]. To analyze the changes in the stability of the hydrolytically active $\mathrm{Pd}$-peptide complex upon ligand 


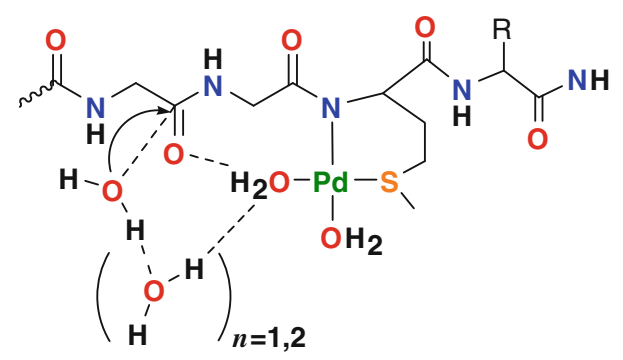

Scheme 2 Hydrolytically active Pd(II) complex

exchange processes, we investigate the effect of ligands en, $\mathrm{Cl}^{-}$, and $\mathrm{NH}_{3}$ on a closely related model complex, $\left[\mathrm{Pd}(\mathrm{Pep})\left(\mathrm{H}_{2} \mathrm{O}\right)_{2}\right]^{+}$, where Pep stands for Ace-Gly-GlyMet-Nme. By using this model for representing the peptide molecule, a relatively high QM level of theory can be employed to compute only relative stability constants among Pd-peptide complexes. Thus, truncation effects and neglect of the conformational freedom of the peptide molecule prevent us from computing absolute binding energies for the formation the Pd-Pep complexes.

We studied the energy change corresponding to several reactive processes that can be envisaged when the $\mathrm{Pd}$ bound water molecules at the $\left[\mathrm{Pd}(\mathrm{Pep})\left(\mathrm{H}_{2} \mathrm{O}\right)_{2}\right]^{+}$and $\left[\mathrm{Pd}\left(\mathrm{H}_{2} \mathrm{O}\right)_{4}\right]^{2+}$ complexes, are substituted by en, $\mathrm{NH}_{3}$ and $\mathrm{Cl}^{-}$. For these processes to occur, an acidic environment is assumed in order to match more closely the experimental conditions. This means that the en and $\mathrm{NH}_{3}$ ligands should be considered to be in their protonated forms as $\mathrm{enH}_{2}{ }^{2+}$ and $\mathrm{NH}_{4}{ }^{+}$, respectively, when they are not bound to the $\operatorname{Pd}(\mathrm{II})$ ion. The chemical equations and the computed energy data are summarized in Table 3 while Fig. 1 displays the optimized geometries of the Pd-bound peptide complexes at the B3LYP/aug-cc-pVTZ (cc-pVTZ-PP for Pd) level of theory. Unless otherwise stated, we will discuss in the text the Gibbs energies in solution.

\subsubsection{Influence of ethylenediamine ligand}

The chelate effect associated to the bidentate en ligand is well reproduced by our calculations. Thus, the cis$\left[\mathrm{Pd}(\mathrm{en})\left(\mathrm{H}_{2} \mathrm{O}\right)_{2}\right]^{2+}$ complex is predicted to be $11.2 \mathrm{kcal} / \mathrm{mol}$ more stable than $\left[\mathrm{Pd}\left(\mathrm{H}_{2} \mathrm{O}\right)_{4}\right]^{2+}$. This free energy difference assumes a $1 \mathrm{M}$ standard concentration of $\mathrm{H}^{+}$in aqueous solution, so that water replacement by en takes place with the release of two $\mathrm{H}^{+}$from the doubly protonated $\mathrm{enH}^{2+}$ species. In Fig. 1, we see that the equilibrium geometry of the corresponding complexes in the presence of the Pep ligand, $\left[\mathrm{Pd}(\mathrm{Pep})\left(\mathrm{H}_{2} \mathrm{O}\right)_{2}\right]^{+}$and $[\mathrm{Pd}(\mathrm{Pep})(\mathrm{en})]^{+}$, is quite similar in terms of the Pep-moiety conformation and the intramolecular $\mathrm{H}$-bonds between the $\mathrm{Pd}$-water/amino groups and the backbone carbonyl group. We note in passing that this structural similarity gives support to the use of these QM cluster models for estimating the relative stability of the Pd-peptide complexes. Interestingly, the computed free energies indicate that water replacement by en stabilizes the Pd-Pep complex by $3.1 \mathrm{kcal} / \mathrm{mol}$, that is, the presence of the Pep ligand diminishes the chelate effect of the en ligand in such a way that the resulting energy difference could be small enough for establishing an equilibrium between the $\left[\mathrm{Pd}(\mathrm{Pep})\left(\mathrm{H}_{2} \mathrm{O}\right)_{2}\right]^{+}$and $[\mathrm{Pd}(\mathrm{Pe}-$ p)(en) ${ }^{+}$complexes.

\subsubsection{Influence of ammonia ligands}

According to our calculations in acid aqueous solution, the predicted stability of the $\mathrm{Pd}$-ammonia complexes with respect to $\left[\mathrm{Pd}\left(\mathrm{H}_{2} \mathrm{O}\right)_{4}\right]^{2+}$ is rather low in consonance with expectation. For example, $\left[\mathrm{Pd}\left(\mathrm{NH}_{3}\right)_{2}\left(\mathrm{H}_{2} \mathrm{O}\right)_{2}\right]^{2+}$ is slightly more stable than the $\mathrm{Pd}(\mathrm{II})$-aqua complex by $0.9 \mathrm{kcal} / \mathrm{mol}$. Moreover, when the experimentally used $\left[\mathrm{Pd}\left(\mathrm{NH}_{3}\right)_{4}\right]^{2+}$ is taken into account in the calculations, the stability is reversed by $7.1 \mathrm{kcal} / \mathrm{mol}$ (see Table 3 ). From a structural point of view, ammonia and water ligands result in very similar $\left[\mathrm{Pd}(\mathrm{Pep})(\mathrm{L})_{2}\right]^{+}$complexes (see Fig. 1), but $\left[\operatorname{Pd}(\mathrm{Pep})\left(\mathrm{NH}_{3}\right)_{2}\right]^{+}$turns out to be $8.4 \mathrm{kcal} / \mathrm{mol}$ less stable than the hydrolytically active species $\left[\mathrm{Pd}(\mathrm{Pep})\left(\mathrm{H}_{2} \mathrm{O}\right)_{2}\right]^{+}$.

\subsubsection{Influence of chloride ligands}

According to our results and taking as reference the $\left[\mathrm{Pd}\left(\mathrm{H}_{2} \mathrm{O}\right)_{4}\right]^{+}$species, the replacement of two and four water ligands by $\mathrm{Cl}^{-}$ions largely stabilizes the $\mathrm{Pd}$-complex by 10.7 and $18.1 \mathrm{kcal} / \mathrm{mol}$, respectively. Similarly, when comparing the relative stability of the $\mathrm{Pd}(\mathrm{II})$ complexes coordinated to the Pep fragment, the $\left[\mathrm{Pd}(\mathrm{Pep})(\mathrm{Cl})_{2}\right]^{-}$ complex is much more stable than the precursor water complex by $17.2 \mathrm{kcal} / \mathrm{mol}$. These figures can be understood in terms of the larger strength of the metal-ligand bonds formed between the $\mathrm{Pd}(\mathrm{II})$ and $\mathrm{Cl}^{-}$ions. However, they should be taken with caution, particularly for the Pd-peptide structures. First, our validation calculations suggest that the quality of the relative stability calculations involving chloro-complexes would be lower than those for the other ligands. Secondly, the use of a tripeptide model instead of the full decapeptide can result in larger truncation effects in the $\left[\mathrm{Pd}(\mathrm{Pep})(\mathrm{Cl})_{2}\right]^{-}$complexes. In effect, as seen in Fig. 1, the optimized $\left[\mathrm{Pd}(\mathrm{Pep})(\mathrm{Cl})_{2}\right]^{-}$structure exhibits a more extended conformation, which deviates significantly from the hairpin shape of $\left[\mathrm{Pd}(\mathrm{Pep})\left(\mathrm{H}_{2} \mathrm{O}\right)_{2}\right]^{+}$, $[\operatorname{Pd}(\mathrm{Pep})(\mathrm{en})]^{+}$and $\left[\mathrm{Pd}(\mathrm{Pep})\left(\mathrm{NH}_{3}\right)_{2}\right]^{+}$. This change is due to the location of a global negative charge around the $\mathrm{Pd}(\mathrm{II})$ ion and the inability of the Pd-bound $\mathrm{Cl}^{-}$ions to establish intramolecular hydrogen bond interactions. Hence, the use of a more realistic model for $\left[\mathrm{Pd}(\mathrm{Pep})(\mathrm{Cl})_{2}\right]^{-}$through the 
Table 3 B3LYP/aug-cc-pVTZ (cc-pVTZ-PP for Pd) electronic energies $(\Delta E)$, B3LYP/aug-cc-pVDZ (cc-pVDZ-PP for Pd) thermal Gibbs energy corrections $\left(\Delta G_{\text {therm }}^{\text {corr }}\right)$, PB-B3LYP/LACVP* + Gibbs energies of solvation $\left(\Delta \Delta G_{\text {solv }}\right)$, and Gibbs energies in solution $\left(\Delta G_{\text {solution }}\right)$ referred to the corresponding reactants in $\mathrm{kcal} / \mathrm{mol}$

\begin{tabular}{|c|c|c|c|c|c|}
\hline Reaction & & $\Delta E$ & $\Delta G_{\text {therm }}^{\text {corr a }}$ & $\Delta \Delta G_{\text {solv }}{ }^{\mathrm{b}}$ & $\Delta G_{\text {solution }}$ \\
\hline$\left[\mathrm{Pd}\left(\mathrm{H}_{2} \mathrm{O}\right)_{4}\right]^{2+}+2 \mathrm{NH}_{4}^{+} \rightarrow$ cis- $\left[\mathrm{Pd}\left(\mathrm{NH}_{3}\right)_{2}\left(\mathrm{H}_{2} \mathrm{O}\right)_{2}\right]^{2+}+2 \mathrm{H}_{2} \mathrm{O}+2 \mathrm{H}^{+}$ & (1) & 373.2 & -25.3 & -348.9 & -0.9 \\
\hline$\left[\mathrm{Pd}\left(\mathrm{H}_{2} \mathrm{O}\right)_{4}\right]^{2+}+4 \mathrm{NH}_{4}^{+} \rightarrow\left[\mathrm{Pd}\left(\mathrm{NH}_{3}\right)_{4}\right]^{2+}+4 \mathrm{H}_{2} \mathrm{O}+4 \mathrm{H}^{+}$ & (2) & 759.6 & -49.6 & -703.0 & 7.1 \\
\hline$\left[\mathrm{Pd}(\mathrm{Pep})\left(\mathrm{H}_{2} \mathrm{O}\right)_{2}\right]^{+}+2 \mathrm{NH}_{4}^{+} \rightarrow\left[\mathrm{Pd}(\mathrm{Pep})\left(\mathrm{NH}_{3}\right)_{2}\right]^{+}+2 \mathrm{H}_{2} \mathrm{O}+2 \mathrm{H}^{+}$ & (3) & 404.9 & -26.1 & -370.4 & 8.4 \\
\hline$\left[\mathrm{Pd}\left(\mathrm{H}_{2} \mathrm{O}\right)_{4}\right]^{2+}+\mathrm{enH}_{2}{ }^{2+} \rightarrow$ cis- $\left[\mathrm{Pd}(\mathrm{en})\left(\mathrm{H}_{2} \mathrm{O}\right)_{2}\right]^{2+}+2 \mathrm{H}_{2} \mathrm{O}+2 \mathrm{H}^{+}$ & (4) & 295.3 & -27.0 & -279.5 & -11.3 \\
\hline$\left[\mathrm{Pd}(\mathrm{Pep})\left(\mathrm{H}_{2} \mathrm{O}\right)_{2}\right]^{+}+\mathrm{enH}_{2}{ }^{2+} \rightarrow[\mathrm{Pd}(\mathrm{Pep})(\mathrm{en})]^{+}+2 \mathrm{H}_{2} \mathrm{O}+2 \mathrm{H}^{+}$ & (5) & 333.4 & -27.9 & -308.7 & -3.1 \\
\hline$\left[\mathrm{Pd}\left(\mathrm{H}_{2} \mathrm{O}\right)_{4}\right]^{2+}+2 \mathrm{Cl}^{-} \rightarrow$ cis $-\left[\mathrm{Pd}\left(\mathrm{H}_{2} \mathrm{O}\right)_{2}(\mathrm{Cl})_{2}\right]+2 \mathrm{H}_{2} \mathrm{O}$ & $(6)$ & -356.2 & -2.3 & 347.8 & -10.7 \\
\hline$\left[\mathrm{Pd}\left(\mathrm{H}_{2} \mathrm{O}\right)_{4}\right]^{2+}+4 \mathrm{Cl}^{-} \rightarrow\left[\mathrm{Pd}(\mathrm{Cl})_{4}\right]^{2-}+4 \mathrm{H}_{2} \mathrm{O}$ & (7) & -340.4 & -6.0 & 328.3 & -18.1 \\
\hline$\left[\mathrm{Pd}(\mathrm{Pep})\left(\mathrm{H}_{2} \mathrm{O}\right)_{2}\right]^{+}+2 \mathrm{Cl}^{-} \rightarrow\left[\mathrm{Pd}(\mathrm{Pep})(\mathrm{Cl})_{2}\right]^{-}+2 \mathrm{H}_{2} \mathrm{O}$ & (8) & -147.5 & -7.2 & 137.5 & -17.2 \\
\hline$\left[\mathrm{Pd}(\mathrm{Pep})\left(\mathrm{H}_{2} \mathrm{O}\right)_{2}\right]^{+} \rightarrow\left[\mathrm{Pd}(\mathrm{Pep})\left(\mathrm{H}_{2} \mathrm{O}\right)\right]+\mathrm{H}_{2} \mathrm{O}+\mathrm{H}^{+}$ & (9) & 248.4 & -18.6 & -232.5 & -2.7 \\
\hline
\end{tabular}

${ }^{\text {a }}$ The correction due to the standard state concentration $\left(1 M\right.$ for all the species except $55 M$ for $\left.\mathrm{H}_{2} \mathrm{O}\right)$ is included. $G_{\text {therm }}\left(\mathrm{H}^{+}\right)=-6.28 \mathrm{cal} /(\mathrm{k} \mathrm{mol})$

${ }^{\text {b Using }} \Delta G_{\text {solv }}\left(\mathrm{H}_{2} \mathrm{O}\right)=-6.3 \mathrm{kcal} / \mathrm{mol}(\exp ) ; \Delta G_{\text {solv }}\left(\mathrm{H}^{+}\right)=-266.0 \mathrm{kcal} / \mathrm{mol}$

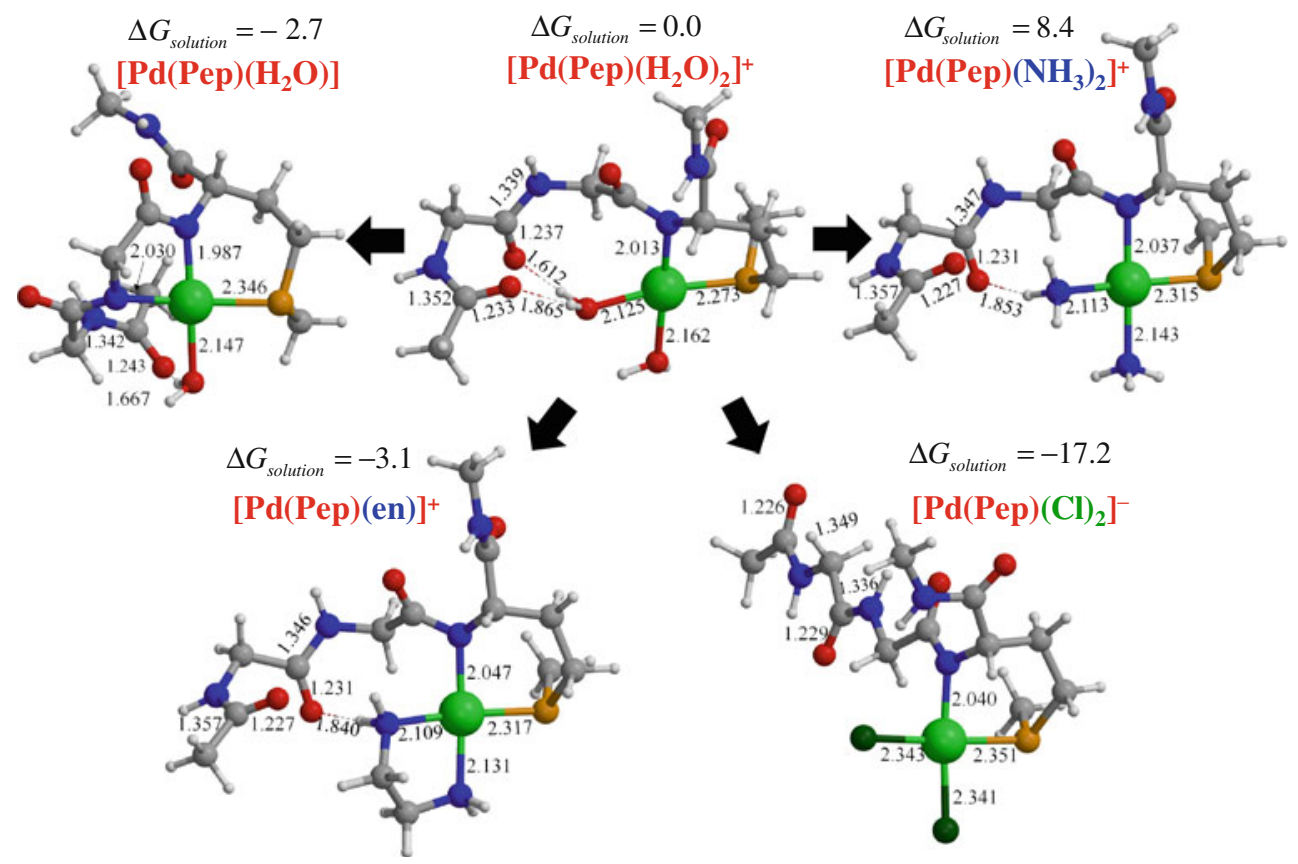

Fig. 1 B3LYP/aug-cc-pVTZ (cc-pVTZ-PP for Pd) optimized geometries of the complexes Pd-Pep complexes of Pd(II) ion investigated in this work. Relative Gibbs energies in solution are also indicated. Distances are given in $\AA$ and energies in $\mathrm{kcal} / \mathrm{mol}$

inclusion in the QM calculations of water molecules and more peptide residues could modify our theoretical findings on the influence of the chloride ligands.

\subsubsection{Deprotonation of $\left[\mathrm{Pd}(\mathrm{Pep})\left(\mathrm{H}_{2} \mathrm{O}\right)_{2}\right]^{+}$}

We also calculated the free energy for the deprotonation of one amide group of the hydrolytically active complex $\left[\mathrm{Pd}(\mathrm{Pep})\left(\mathrm{H}_{2} \mathrm{O}\right)_{2}\right]^{+}$with simultaneous release of a Pd-bound water molecule, leading thus to a $\left[\mathrm{Pd}(\mathrm{Pep})\left(\mathrm{H}_{2} \mathrm{O}\right)\right]$ complex in which the $\mathrm{Pd}$ ion is bound to two $\mathrm{N}$ and one $\mathrm{S}$ donor atoms of the peptide plus the remaining water molecule (see Fig. 1). The resulting structure is a model of complex 3 in Scheme 1, so that the computed change in the standard free energy in solution, which amounts to $-2.7 \mathrm{kcal} / \mathrm{mol}$, can give some indication about the stability of the reactive complex 2 with respect to the acidity of the solution.

\subsubsection{Implications for peptide hydrolysis}

The mechanistic proposal that the $\left[\mathrm{Pd}(\mathrm{Pep})\left(\mathrm{H}_{2} \mathrm{O}\right)_{2}\right]^{+}$ complex is the hydrolytically active species regardless the 
identity of the ligands initially bound to the $\mathrm{Pd}(\mathrm{II})$ cation at the reactant state is supported by various experimental evidences: the coincidental order of magnitude of the rate determining constants measured for the $\left[\mathrm{Pd}\left(\mathrm{H}_{2} \mathrm{O}\right)_{4}\right]^{2+}$, $\left[\mathrm{Pd}\left(\mathrm{NH}_{3}\right)_{4}\right]^{2+}, \quad$ cis- $\left[\mathrm{Pd}(\mathrm{en})\left(\mathrm{H}_{2} \mathrm{O}\right)_{2}\right]^{2+}$ and $\left[\mathrm{Pd}(\mathrm{Cl})_{4}\right]^{2-}$ complexes, the fact that all of them present the same regioselectivity toward peptide hydrolysis, and the $\mathrm{pH}$ kinetic effects showing that the rate of the reaction increases with acidity [28]. Although the $\mathrm{Pd}(\mathrm{II})$-assisted peptide hydrolysis processes have practical rates at $20-40{ }^{\circ} \mathrm{C}$, they are not extremely fast and, therefore, it can be reasonably expected that pseudo-equilibrium processes among different $\mathrm{Pd}(\mathrm{II})$-complexes with various ligands including the reactive complex, $\left[\mathrm{Pd}(\mathrm{pep})\left(\mathrm{H}_{2} \mathrm{O}\right)_{2}\right]^{2+}$, could affect the rate of the reaction and modulate the value of the apparent firstorder kinetic constant on the peptide concentration. In this mechanistic scenario, the calculations reported in this work provide new insight by showing that the different experimental reaction rate of peptide hydrolytic cleavage promoted by the complexes $\left[\mathrm{Pd}\left(\mathrm{H}_{2} \mathrm{O}\right)_{4}\right]^{2+}\left(0.24 \mathrm{~h}^{-1}\right)$, $\left[\mathrm{Pd}\left(\mathrm{NH}_{3}\right)_{4}\right]^{2+}\left(0.25 \mathrm{~h}^{-1}\right)$, cis- $\left[\mathrm{Pd}(\mathrm{en})\left(\mathrm{H}_{2} \mathrm{O}\right)_{2}\right]^{2+}\left(0.14 \mathrm{~h}^{-1}\right)$, and $\left[\mathrm{Pd}(\mathrm{Cl})_{4}\right]^{2-}\left(0.13 \mathrm{~h}^{-1}\right)[28]$ can be correlated with the relative stability of the complexes $\left[\mathrm{Pd}(\mathrm{Pep})\left(\mathrm{NH}_{3}\right)_{2}\right]^{+}$, $[\mathrm{Pd}(\mathrm{Pep})(\mathrm{en})]^{+}$, and $\left[\mathrm{Pd}(\mathrm{Pep})(\mathrm{Cl})_{2}\right]^{-}$compared to $[\mathrm{Pd}(\mathrm{Pe}-$ p) $\left.\left(\mathrm{H}_{2} \mathrm{O}\right)_{2}\right]^{+}$and other related ligand exchange processes (see Table 3). Particularly, our calculations help understanding qualitatively why complexes in which $\mathrm{Pd}(\mathrm{II})$ ion carries labile ligands, $\left[\mathrm{Pd}\left(\mathrm{H}_{2} \mathrm{O}\right)_{4}\right]^{2+}$ and $\left[\mathrm{Pd}\left(\mathrm{NH}_{3}\right)_{4}\right]^{2+}$, are more reactive than those containing an anionic ligand, $\left[\mathrm{Pd}(\mathrm{Cl})_{4}\right]^{2-}$, or a bidetante ligand, cis- $\left[\mathrm{Pd}(\mathrm{en})\left(\mathrm{H}_{2} \mathrm{O}\right)_{2}\right]^{2+}$.

In the case of $\left[\mathrm{Pd}\left(\mathrm{NH}_{3}\right)_{4}\right]^{2+}$, our results indicate that this complex would not be stable at the low pHs required for the reaction to occur, and the predicted free energy of other species like $\left[\mathrm{Pd}\left(\mathrm{H}_{2} \mathrm{O}\right)_{2}\left(\mathrm{NH}_{3}\right)_{2}\right]^{2+}$ would be close to that of $\left[\mathrm{Pd}\left(\mathrm{H}_{2} \mathrm{O}\right)_{4}\right]^{2+}$. This means that, starting from $\left[\mathrm{Pd}\left(\mathrm{NH}_{3}\right)_{4}\right]^{2+}$, peptide binding to the $\mathrm{Pd}(\mathrm{II})$ ion could form directly the reactive aqua-complex, $\left[\mathrm{Pd}(\mathrm{Pep})\left(\mathrm{H}_{2} \mathrm{O}\right)_{2}\right]^{2+}$. Moreover, we found that the equivalent ammonia complex, $\left[\mathrm{Pd}(\mathrm{Pep})\left(\mathrm{NH}_{3}\right)_{2}\right]^{2+}$ is much less stable. Hence, we conclude that ammonia behaves as a more labile ligand than water, regardless of the presence or not of the Pd-bound peptide molecule, explaining thus the practically identical reaction rate of $\left[\mathrm{Pd}\left(\mathrm{H}_{2} \mathrm{O}\right)_{4}\right]^{2+}$ and $\left[\mathrm{Pd}\left(\mathrm{NH}_{3}\right)_{4}\right]^{2+}$.

A more complex behavior can be expected in the case of the ethylenediamine $\mathrm{Pd}$ (II) complex because our calculations point out that the ligand chelate effect is still present at low $\mathrm{pH}$ values. Thus, it is not probable that water molecules can displace the en ligand before peptide binding takes place. Alternatively, we predict that the peptide molecule binds first to cis- $\left[\mathrm{Pd}(\mathrm{en})\left(\mathrm{H}_{2} \mathrm{O}\right)_{2}\right]^{2+}$, forming thus the $[\operatorname{Pd}(\operatorname{Pep})(\mathrm{en})]^{+}$complex which, in turn, could be in equilibrium with the reactive $\left[\mathrm{Pd}(\mathrm{Pep})\left(\mathrm{H}_{2} \mathrm{O}\right)_{2}\right]^{+}$complex as the latter one is only about $3 \mathrm{kcal} / \mathrm{mol}$ less stable in terms of standard free energy. In this way, the hydrolytic delay experimentally observed can be attributed to a slow displacement of the bidentate en ligand by two water molecules instead of by the $\mathrm{N}$ and $\mathrm{S}$ donor atoms in peptide as experimentally suggested [28].

As indicated before, the first-order rate constant for the cis- $\left[\mathrm{Pd}(\mathrm{en})\left(\mathrm{H}_{2} \mathrm{O}\right)_{2}\right]^{2+}$ and $\left[\mathrm{Pd}(\mathrm{Cl})_{4}\right]^{2-}$ complexes reacting with the peptide molecules is nearly identical $(0.14$ and $\left.0.13 \mathrm{~h}^{-1}\right)$ [28]. Our calculations show again that $\left[\mathrm{Pd}(\mathrm{Pep})(\mathrm{Cl})_{2}\right]^{-}$is more stable than $\left[\mathrm{Pd}(\mathrm{Pep})\left(\mathrm{H}_{2} \mathrm{O}\right)_{2}\right]^{+}$, what is in qualitative agreement with the observed kinetic effect for the $\mathrm{Cl}^{-}$ligands. However, the calculated

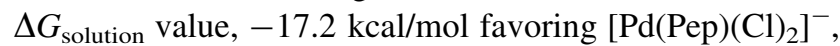
is clearly too large in absolute value for explaining the similar rate constants experimentally reported for the en and $\mathrm{Cl}^{-}$ligands. As previously noticed, two computational facts can justify this discrepancy: a poorer theoretical description of the $\mathrm{Pd}-\mathrm{Cl}$ bond energies and larger truncation effects due to the use of a cluster model in our QM calculations. We believe that truncation effects play a more important role since the stability constants of the small $\left[\mathrm{Pd}\left(\mathrm{H}_{2} \mathrm{O}\right)_{2} \mathrm{Cl}_{2}\right]$ and $\left[\mathrm{PdCl}_{4}\right]^{2-}$ complexes are actually underestimated according to our benchmarking calculations (see Table 2). Nevertheless, the possibility that the peptide hydrolysis reaction could also take place at the $\left[\mathrm{Pd}(\mathrm{Pep})(\mathrm{Cl})_{2}\right]^{-}$complex through the attack of an external water molecule cannot be ruled out.

The rate constant for the regioselective peptide hydrolysis induced by the $\mathrm{Pd}(\mathrm{II})$ complexes increases with acidity. On the basis of NMR experiments, it has been demonstrated that at $\mathrm{pH} 2.3$ the only $\mathrm{Pd}(\mathrm{II})$-peptide complexes are $\mathbf{2}$ and $\mathbf{3}$ (see Scheme 1). Our calculations show again a reasonable agreement with these experimental observations because the standard free energy change for the $\left[\mathrm{Pd}(\mathrm{Pep})\left(\mathrm{H}_{2} \mathrm{O}\right)_{2}\right]^{+} \rightarrow\left[\mathrm{Pd}(\mathrm{Pep})\left(\mathrm{H}_{2} \mathrm{O}\right)\right]+\mathrm{H}_{2} \mathrm{O}+\mathrm{H}^{+}$ reaction is not large, $-2.7 \mathrm{kcal} / \mathrm{mol}$, and thereby an acidbase equilibrium between the two $\mathrm{Pd}(\mathrm{II})$ complexes representing $\mathbf{2}$ and $\mathbf{3}$ can be expected: the lower $\mathrm{pH}$, the larger concentration of $\mathbf{2}$.

\section{Summary and conclusions}

In this work, we present benchmark ab initio calculations on small $\mathrm{Pd}(\mathrm{II})$ complexes that together with a careful comparison with experimental data $\left(\mathrm{p} K_{\mathrm{a}}\right.$ and stability constants) allow us to propose the combination of the B3LYP/aug-cc-pVTZ level of theory with the PB-B3LYP/ LACVP* + solvation energies in order to estimate reliable free energies in solution for $\mathrm{Pd}$-peptide complexes with different ligands: $\mathrm{H}_{2} \mathrm{O}, \mathrm{NH}_{3}$, en and $\mathrm{Cl}^{-}$. This computational protocol, which could be useful to analyze other problems related with the relative stability of metal- 
peptide complexes, allow us to study the ligand effects on the kinetics of cleavage of Ace-Ala-Lys-Tyr-Gly-Gly-MetAla-Ala-Arg-Ala promoted by different Pd(II) complexes. Thus, our calculations confirm that complexes in which the $\mathrm{Pd}(\mathrm{II})$ ion carries labile ligands such as $\left[\mathrm{Pd}\left(\mathrm{H}_{2} \mathrm{O}\right)_{4}\right]^{2+}$ and $\left[\mathrm{Pd}\left(\mathrm{NH}_{3}\right)_{4}\right]^{2+}$ would be more effective than those containing a bidentate ligand, such as $c i s-\left[\mathrm{Pd}(\mathrm{en})\left(\mathrm{H}_{2} \mathrm{O}\right)_{2}\right]^{2+}$, or anionic ligands, such as $\left[\mathrm{PdCl}_{4}\right]^{2-}$, as promoters of the cleavage. Besides, we propose a more detailed explanation of the experimental facts on the basis of the computed relative stability of the various Pd-peptide complexes with respect to the hydrolytically active complex $[\mathrm{Pd}(\mathrm{pep}-$ tide $\left.)\left(\mathrm{H}_{2} \mathrm{O}\right)_{2}\right]^{+}$and on the assumption of an initial formation of the respective peptide-bound complexes, which subsequently evolve to give $\left[\mathrm{Pd}(\text { peptide })\left(\mathrm{H}_{2} \mathrm{O}\right)_{2}\right]^{2+}$. The greater or lower labile character of the ligands en, $\mathrm{Cl}^{-}$, and $\mathrm{NH}_{3}$ compared to $\mathrm{H}_{2} \mathrm{O}$ coordinated to $\mathrm{Pd}$ seems to control the relative stability of the $\mathrm{Pd}$-peptide complexes investigated in this work and, as a consequence, the global rate constant of peptide cleavage.

Acknowledgments The authors thank financial support from the Ministerio de Ciencia e Innovación of Spain via project CTQ200763266.

\section{References}

1. Beynon R, Bond JS (2001) Proteolytic enzymes. Oxford University, New York

2. Colland F, Fujita N, Ishihama A, Kolb A (2002) Genes Cells 7:233

3. Heyduk T, Baichoo N, Heyduk E (2001) Metal Ions Biol Syst 38:255

4. Hubbard S, Beynon RJ (2001) Proteolysis of native proteins as structural probe. Oxford University, New York

5. Loizos N (2004) Method Mol Biol 261:199

6. Thomas JJ, Bakhtiar R, Siuzdak G (2000) Acc Chem Res 33:179

7. Chae PS, Kim M-S, Jeung C-S, Lee SD, Park H, Lee S, Suh J (2005) J Am Chem Soc 127:2396

8. Grant KB, Kassai M (2006) Curr Org Chem 10:1035

9. Jeon JW, Son SJ, Yoo CE, Hong IS, Suh J (2003) Bioorg Med Chem 11:2901

10. Kassai M, Ravi RG, Shealy SJ, Grant KB (2004) Inorg Chem 43:6130

11. Allen G (2001) Metal Ions Biol Syst 38:197

12. Buckingham DA, Clark CR (2001) Metal Ions Biol Syst 38:43

13. Datwyler SA, Meares CF (2001) Metal Ions Biol Syst 38:213

14. Erxleben A (2005) Inorg Chem 44:1082

15. Milovic NM, Kostic NM (2003) J Am Chem Soc 125:781

16. Takarada T, Yashiro M, Komiyama M (2000) Chem Eur J 6:3906

17. Ghaim JB, Greiner DP, Meares CF, Gennis RB (1995) Biochemistry $34: 11311$

18. Miyake R, Owens JT, Xu D, Jackson WM, Meares CF (1999) J Am Chem Soc 121:7453

19. Dutca LM, Ko KS, Pohl N, Kostic NM (2005) Inorg Chem 44:5141

20. Johnson TW, Kostic NM (2004) J Serb Chem Soc 69:887

21. Johnson TW, Kostic NM (2006) J Serb Chem Soc 69:887
22. Kaminskaia NV, Kostic NM (2001) Inorg Chem 40:2368

23. Milinkovic SU, Parac TN, Djuran MI, Kostic NM (1997) J Chem Soc Dalton Trans 2771

24. Milovic NM, Badjic JD, Kostic NM (2004) J Am Chem Soc 126:696

25. Milovic NM, Dutca LM, Kostic NM (2003) Inorg Chem 42:4036

26. Milovic NM, Dutca LM, Kostic NM (2003) Chem Eur J 9:5097

27. Milovic NM, Kostic NM (2001) Metal Ions Biol Syst 38:145

28. Milovic NM, Kostic NM (2002) J Am Chem Soc 124:4759

29. Milovic NM, Kostic NM (2002) Inorg Chem 41:7053

30. Parac TN, Kostic NM (1996) J Am Chem Soc 118:51

31. Parac TN, Kostic NM (1996) J Am Chem Soc 118:5946

32. Parac TN, Kostic NM (1998) Inorg Chem 37:2141

33. Parac TN, Ullmann GM, Kostic NM (1999) J Am Chem Soc 121:3127

34. Stoffregen SA, Griffin AKK, Kostic NM (2005) Inorg Chem 44:8899

35. Sun XJ, Zhang L, Zhang Y, Yang GS, Guo ZJ, Zhu L (2003) New J Chem 27:818

36. Yang G, Miao R, Li Y, Hong J, Zhao C, Guo Z, Zhu L (2005) J Chem Soc Dalton Trans 1613

37. Zhu L, Kostic NM (1992) Inorg Chem 31:3994

38. Zhu L, Kostic NM (1993) J Am Chem Soc 115:4566

39. Zhu L, Kostic NM (2002) Inorg Chim Acta 339:104

40. Zhu L, Qin L, Parac TN, Kostic NM (1994) J Am Chem Soc 116:5218

41. Zirkovic MD, Rajkovic S, Rychlewka O, Warzajtis B, Djuran MI (2007) Polyhedron 26:1541

42. Yeguas V, Campomanes P, López R, Díaz N, Suárez D (2010) J Phys Chem B 114:8525-8535

43. Siegbahn PEM (2003) Rev Biophys 36:91

44. Becke AD (1988) Phys Rev A 38:3098

45. Becke AD (1993) J Chem Phys 98:5648

46. Lee C, Yang W, Parr RG (1988) Phys Rev B 37:785

47. Dunning TH Jr (1989) J Chem Phys 90:1007

48. Kendall RA, Dunning TH Jr, Harrison RJ (1992) J Chem Phys 96:6796

49. Peterson KA (2007) Annu Rep Comput Chem 3:195

50. Peterson KA, Figgen D, Dolg M, Stoll H (2007) J Chem Phys 126:124101

51. Woon DE, Dunning TH Jr (1993) J Chem Phys 98:1358

52. Raghavachari K, Trucks GW, Pople JA, Head-Gordon M (1989) Chem Phys Lett 157:479

53. Frisch MJ, Trucks GW, Schlegel HB, Scuseria GE, Robb MA, Cheeseman JR, Montgomery JA, Vreven JT, Kudin KN, Burant JC, Millam JM, Iyengar SS, Tomasi J, Barone V, Mennucci B, Cossi M, Scalmani G, Rega N, Petersson GA, Nakatsuji H, Hada M, Ehara M, Toyota K, Fukuda R, Hasegawa J, Ishida M, Nakajima T, Honda Y, Kitao O, Nakai H, Klene M, Li X, Knox JE, Hratchian HP, Cross JB, Adamo C, Jaramillo J, Gomperts R, Stratmann RE, Yazyev O, Austin AJ, Cammi R, Pomelli C, Ochterski JW, Ayala PY, Morokuma K, Voth GA, Salvador P, Dannenberg JJ, Zakrzewski VG, Dapprich S, Daniels AD, Strain MC, Farkas O, Malick DK, Rabuck AD, Raghavachari K, Foresman JB, Ortiz JV, Cui Q, Baboul AG, Clifford S, Cioslowski J, Stefanov BB, Liu G, Liashenko A, Piskorz P, Komaromi I, Martin RL, Fox DJ, Keith T, Al-Laham MA, Peng CY, Nanayakkara A, Challacombe M, Gill PMW, Johnson B, Chen W, Wong MW, Gonzalez C, Pople JA (2003) Gaussian 03, Revision A.1. Gaussian Inc., Wallingford

54. Ahlrichs R, Bär M, Baron HP, Rüdiger B, Böcker S, Crawford N, Deglmann P, Ehrig M, Eichkorn K, Elliot S, Furche F, Haase F, Häser M, Horn H, Hättig C, Huber C, Huniar U, Kattannek M, Köhn A, Kölmel C, Kollwitz M, May K, Nava P, Ochsenfeld C, Öhm H, Patzelt H, Rappoport D, Rubner O, Schäfer A, Schneider U, Sierka M, Treutler O, Unterreiner B, von Arnim M, Weigend 
F, Weis P, Weiss H (2005) TURBOMOLE, version 5.9. Karlsruhe, Germany

55. Werner HJ, Knowles PJ, Lindh R, Manby FR, Schütz M, Celani P, Korona K, Rauhut G, Amos RD, Bernhardsson A, Berning A, Cooper DL, Deegan MJO, Dobbyn AJ, Eckert F, Hampel C, Hetzer G, Lloyd AW, McNicholas SJ, Meyer W, Mura ME, Nicklass A, Palmieri P, Pitzer R, Schumann U, Stoll H, Stone AJ, Tarroni R, Thorsteinsson T (2008) MOLPRO, version 2008.1, a package of ab initio programs. Cardiff, UK

56. Peterson KA, Puzzarini C (2005) Theor Chem Acc 114:283

57. Curutchet C, Cramer CJ, Truhlar DG, Ruiz-López MF, Rinaldi D, Orozco M, Luque FJ (2002) J Comput Chem 24:284

58. Tomasi J, Persico M (1994) Chem Rev 94:2027

59. Claverie P (1982) In: Daudel R, Pullman A, Salem L, Veillard A (eds) Quantum theory of chemical reactions, vol III. Reidel, Dordrecht, p 151

60. Jaguar (2004) Schrödinger, L. L. C., Portland

61. Hay PJ, Wadt WR (1985) J Chem Phys 82:299

62. Hehre WJ, Radom L, Pople JA, Schleyer PVR (1986) Ab initio molecular orbital theory. Wiley, New York
63. Takano Y, Houk KN (2005) J Chem Theory Comput 1:70

64. Tawa GJ, Topol IA, Burt SK, Caldewll RA, Rashin AA (1998) J Chem Phys 109:4852

65. Goncalves PFB (2004) Pure Appl Chem 76:231

66. Beret EC, Pappalardo RR, Doltsinis NL, Marx D, SánchezMarcos E (2008) Chem Phys Chem 9:237

67. Beret EC, Martínez JM, Pappalardo RR, Sánchez-Marcos E, Doltsinis NL, Marx D (2008) J Chem Theory Comput 4:2108

68. Martínez JM, Torrico F, Pappalardo RR, Sánchez-Marcos E (2004) J Phys Chem B 108:15851

69. Serjeant E, Dempsey B (1979) Ionization constants of organic acids in solution. In: IUPAC Chemical Data Series No. 23. Pergamon Press, Oxford

70. Pliego JR Jr, Riveros JM (2000) Chem Phys Lett 332:597

71. Shi T, Elding LI (1998) Acta Chem Scand 52:897

72. Martell AE, Smith RL (1989) Critical stability constants. Plenum Press, New York (and references therein)

73. Martell AE, Sillén LG (1968) Stability constants of metal-ion complexes. London 